\title{
Notes
}

\section{Synthesis and Metal Binding Properties of Anthraquinone Bridged with Coumarin}

\author{
Byung Ju Ryu, Eun Jin Cho, and Kyc Chun Nam" \\ Deparment of Chemisty, Chonnam National Universily, Gwangiu 500-757. Korea. ${ }^{*}$ E-mail: kenamiaj,chomamac.kr \\ Received June 21. 2007
}

Key Words : Anthraquinone, Coumarin, Metal binding

Molecular switching in macrocyclic polyether systems has been the subject of intense study during the past 30 years. Especially, photochemical switching has been well-studied by Shinkai, Ueno. Takagi, Tabushi, and others.' In addition. changes in $\mathrm{pH}_{,}^{2}$ light ${ }^{3}$ and oxidation-reduction chemistry ${ }^{+}$ have all been explored as switching mechanisms.

The lariat ethers. ${ }^{5}$ podands having nitroaromatic sidearms ${ }^{6}$ and similar species derived from anthraquinones have been concerned with electrochemical switching. Especially the anthraquinone system is an interesting one for the study of reducible and switchable lariat ethers ${ }^{7}$ because its anion is stable for months in water so long as oxygen is excluded. Although podands (noncyclic polyethylene glycols) generally exhibit poor cation binding. when combined with the semiquinone nucleus, very strong cation complexation is observed for the radical anion. ${ }^{3.9}$ The anthraquinone podands can be used for electrochemically switched cation transport in bulk organic membranes ${ }^{\text {tb }}$ and both monoanion and dianion species can be formed and detected. ${ }^{10}$ Both oneelectron and wo-clectron reduction can lead to enhanced cation binding in anthraquinone-derived podands and lariat ethers. ${ }^{7 a}$ Anthraquinones differ significantly from the nitroaromatic systems in their ability to undergo discrete one or two electron reduction and also anthraquinone substituted podands exhibit surprising geometrical elfects during the electrochemical switching process. ${ }^{76}$ Gokel and co-workers ${ }^{10}$ have reported two armed podands based on the anthraquinone ring systems, which showed the cation binding enhancement by cyclic voltammetry. 1,8-Anthraquinone derived crown ether having a total of six oxygen donors in the macrocycling is an exceptionally strong cation binder nol only when reduced, but in its neutral form as well.

Anthraquinone plays an important role in the various photochemical and colorimetric sensor systems. In addition. coumarins" are interesting chromophores by their photochemical and photophysical properties, and have been used to convert crown ethers into fluorescent probes for alkali metal ions. Herein we synthesized a new cation receptor 4 which combined coumarin and anthraquinone with ether units, and studied the binding properties of cation guesis.

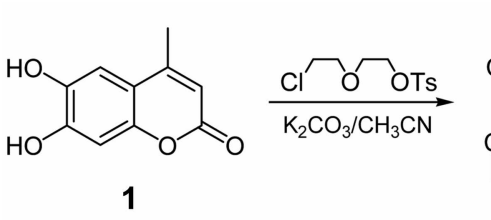<smiles>Cc1cc(=O)oc2cc(OCCOCCCl)c(OCCOCCCl)cc12</smiles>

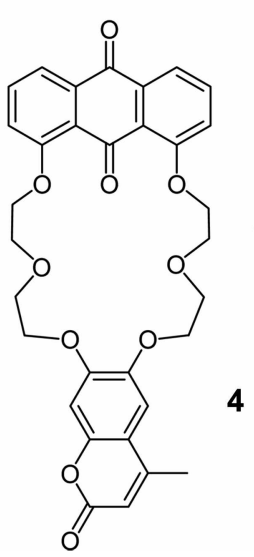<smiles>CCCOCCOc1cc2c(C)cc(=O)oc2cc1OCCOCCI</smiles>

4 3

Scheme 1. Synthesis of receptor 4.

\section{Results and Diseussion}

The receptor 4 was prepared by the reaction of 1.8 dihydroxyanthraquinone and 6,7-bis|2-(2-iodocthoxy)ethyl|loxy-4-methylcoumarin 3 in the presence of potassium carbonate in $42 \%$ yield. Iodo derivative 3 was obtained from 2, which was synthesized from the reaction of 1 and toluene4-sulfonic acid 2-(2-chloroethoxy)ethyl ester, in order to increase the reactivity by treating with $\mathrm{Nal}$.

The 'H NMR spectrum of $\mathbf{4}$ shows two doublets and a triplet at $\delta 7.85,7.62$ and $\delta 7.28$ for six anthraquinone protons and three singlets at $\delta 7.09,6.84$ and 6.13 for three coumarin protons. Also two multiplets at $\delta 4.30-3.90$ for sixteen ether protons and a singlet at $\delta 2.34$ for methyl protons are observed.

The alkali metal binding properties were investigated Irom two phase extraction experiment where aqueous solutions of the picrate salis are shaken with methylene chloride solution of ligand. The amount of metal ion was determined from 
Table 1. Percentage extraction ${ }^{c t}(\%$ E) of alkali picrates from water into $\mathrm{CH}_{2} \mathrm{Cl}_{2}$

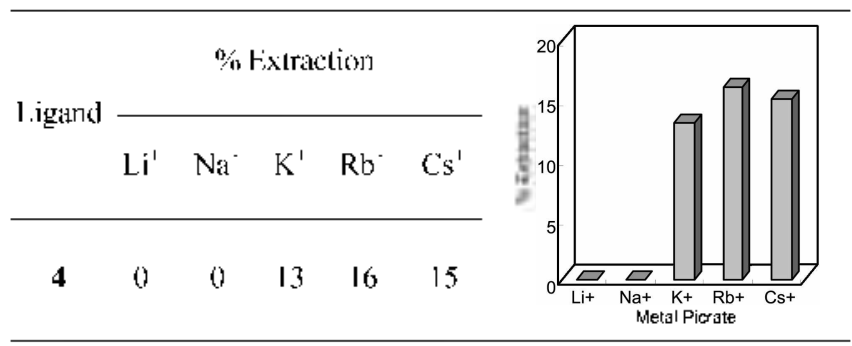

"I $\times 10^{-3} \mathrm{M}$ receptor solution in $\mathrm{Cl}_{2} \mathrm{Cl}_{2}$ wals shaken $(15 \mathrm{hrs}$ ) with $\mathrm{I} \times$ $10^{4} \mathrm{M}$ picrate sall solution in $\mathrm{H}_{2} \mathrm{O}$.

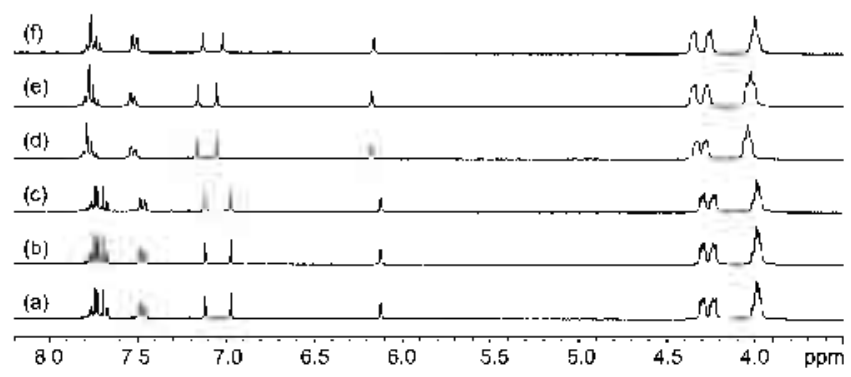

Figure 1. 'I I NMR spectra of 4 (a) without cation (b) with $10 \mathrm{cq}$. of $\mathrm{LiClO}_{4}(\mathrm{c})$ with $10 \mathrm{cq}$. of $\mathrm{NaClO}_{4}(\mathrm{~d})$ with $10 \mathrm{ccl}$. of $\mathrm{KClO}_{4}(\mathrm{c})$ with $10 \mathrm{eq}$. of $\mathrm{RbClO}_{+}$(f) with $10 \mathrm{eq}$ of $\mathrm{CsClO}$ in $\mathrm{CD}_{3} \mathrm{C} / \mathrm{CDMSO}-d_{\text {t }}$ (viv $3: 2)$

picrate absorption in the UV spectrum. Table 1 showed the percent extraction of metal picrate salts by ligand 4 . The ligand 4 extracted $16 \%$ of the rubidium picrate from aqueous solution into the methylene chloride solution of the host, and also $13 \%$ of the potassium and $15 \%$ cesium were extracted. However, no extraction of lithium and sodium ions were observed.

The cation binding properties of 4 were examined by ' $\mathrm{H}$ NMR experiments in $\mathrm{CD}_{3} \mathrm{CN} / \mathrm{DMSO}-d_{s}(\mathrm{v} / \mathrm{v}=3: 2)$. The addition of 10 equivalent of $\mathrm{KClO}_{4}, \mathrm{RbClO}_{4}$ and $\mathrm{CsClO}_{4}$ caused a sinall downfield shift of all peaks. However, the other alkali ions such as $\mathrm{LiClO}_{4}$ and $\mathrm{NaClO}_{4}$ were not changed as shown in Figure 1.

A clear selectivity between relatively large cations such as potassium, rubidium and cesium ions was not observed. Even though a binding site of receptor $\mathbf{4}$ can be an equivalent of 22-crown-7 which could prefer the binding of the larger cation such as cesium, a rigid anthraquinone moiety might prevent the adjustment for the large cation. But as expected from the extraction study, no changes of chemical shifts were observed in the presence of lithium and sodium cations, indicating that sodium and lithium cations are too small for the effective binding with 4 . Therefore, a clear binding selectivity between relatively large cations such as potassium, rubidium and cesium ions and small cations such as sodium and lithium were observed. Optical properties of 4 in the presence of alkali cations were investigated, but any noticeable changes were not observed.

\section{Experimental}

6,7-Bis|2-(2-chloroethoxy)ethy||loxy-4-methylcoumarin (2). To a stirred solution of $0.5 \mathrm{~g}(2.6 \mathrm{mmol})$ of $6,7-$ dihydroxy-4-methylcoumarin 1 and $2.16 \mathrm{~g}$ (15.6 mmol) of $\mathrm{K}_{2} \mathrm{CO}_{3}$ in $100 \mathrm{ml}$ of $\mathrm{CH}_{3} \mathrm{CN}, 1.45 \mathrm{~g}(5.2 \mathrm{mmol})$ of toluene4-sulfonic acid 2-(2-chloro-ethoxy)-ethyl ester prepared by the reaction of 2-(2-chloroethoxy)ethanol with $p$-toluenesulfonyl chloride was added and the reaction mixture was refluxed for $8 \mathrm{~h}$. The solvent was removed and residue was taken up in $\mathrm{CHCl}_{3}(100 \mathrm{ml}$.) and washed with $0.1 \mathrm{~N} \mathrm{HCl}$ $(100 \mathrm{ml}$.) and water. The organic phase was separated and dried with $\mathrm{MgSO}_{4}$ and the crude products was purified by column chromatography (eluent. $\mathrm{CHCl}_{3} ; n$-Hexane:Ethyl acetate $=2: 1: 1)$ to yield $0.7 \mathrm{~g}(67 \%)$ of white powder $2 .{ }^{\mathrm{l}} \mathrm{H}$ NMR $\left(\mathrm{CDCl}_{3}\right) \delta 7.09(\mathrm{~s}, 1 \mathrm{H}, \mathrm{ArH}), 6.84(\mathrm{~s}, 1 \mathrm{H}, \mathrm{ArH}), 6.16$ (d, $1 \mathrm{H}, \mathrm{ArH}, J=1.1 \mathrm{~Hz}), 4.25-3.67\left(\mathrm{~m}, 16 \mathrm{H},-\mathrm{CH}_{2} \mathrm{CH}_{2}\right.$ ), $2.39\left(\mathrm{~d}, 3 \mathrm{H}_{,} \mathrm{CH}_{3}, J=1.1 \mathrm{~Hz}\right.$ ).

6,7-Bis|2-(2-iodoethoxy)ethyl|loxy-4-methylcoumarin (3). 'lo a stirred solution of $0.30 \mathrm{~g}(0.74 \mathrm{mmol})$ of $6.7-\mathrm{Bis}$ [2(2-iodoethoxy)ethyl]loxy-4-methylcoumarin and $1.10 \mathrm{~g}$ (7.34 mmol) of $\mathrm{Nal}$ in $30 \mathrm{~mL}$ of $\mathrm{CH}_{3} \mathrm{CN}$ was added and the reaction mixture was stirred for 2 days. The solvent was removed and residue was taken up in $\mathrm{CHCl}_{3}(100 \mathrm{ml})$ and washed with water. The organic phase was separated and dried with $\mathrm{MgSO}_{4}$ and evaporated to yield $0.20 \mathrm{~g}(69 \%)$ of powder 3. ${ }^{\mathrm{H}} \mathrm{H}$ NR $\left(\mathrm{CDCl}_{3}\right) \delta 7.08(\mathrm{~s}, 1 \mathrm{H}, \mathrm{ArH}), 6.86(\mathrm{~s}$, I H, ArH), 6.16 (s, lH, ArH), 4.24-4.21 (m, 4H, $-\mathrm{CH}_{2} \mathrm{CH}_{2}$ ), $3.96-3.84\left(\mathrm{~m}, 8 \mathrm{H},-\mathrm{CH}_{2} \mathrm{CH}_{2}\right), 3.33-3.27\left(\mathrm{~m}, 4 \mathrm{H},-\mathrm{CH}_{2} \mathrm{CH}_{2}\right)$, $2.39\left(\mathrm{~s}, 3 \mathrm{H}, \mathrm{CH}_{3}\right)$.

1,8-(Ethoxyethyloxy-4-methylcoumarin)-anth rquinone (4). Jo a solution of 1.8-dihydroxyanthraquinone $(0.20 \mathrm{~g}$. $0.83 \mathrm{mmol})$ and $\mathrm{K}_{2} \mathrm{CO}_{3}(1.20 \mathrm{~g} .8 .70 \mathrm{mmol})$ in $60 \mathrm{ml}$. of [HHFDMF (2:1), 6,7-bis[2-(2-iodoethoxy)ethyl]loxy-4methylcoumarin $3(0.50 \mathrm{~g}, 0.85 \mathrm{mmol})$ was added and the reaction mixture was stirred and refluxed for 3 days. The solvent was removed and residue was taken up in $\mathrm{MeOH}$ (50 $\mathrm{mL}$ ). The residue was filtered and treated with $0.1 \mathrm{~N} \mathrm{HCl}$ and extracted with $\mathrm{CHCl}_{3}$. The organic phase was separated and dried with $\mathrm{MgSO}_{4}$ and evaporated to yield $0.20 \mathrm{~g} \mathrm{(42 \% )}$

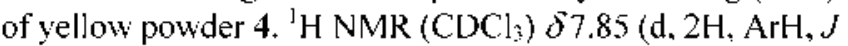
$=7.5 \mathrm{~Hz}), 7.62(\mathrm{t}, 2 \mathrm{H}, \mathrm{ArH}, J=8.1 \mathrm{~Hz}), 7.28(\mathrm{~d}, 2 \mathrm{H}, \mathrm{ArH})$, 7.09 (s, 1H, ArH), 6.84 (s, IH, ArH), 6.13 (s, IH, ArH). $4.29-4.17\left(\mathrm{~m}, 16 \mathrm{H},-\mathrm{CH}_{2} \mathrm{CH}_{2}-\right), 2.34\left(\mathrm{~s}, 3 \mathrm{H}_{4}-\mathrm{CH}_{3}\right)$.

Acknowledgment. This work was supported by the Ministry of Education of Korea (BK 21 project).

\section{References}

1. (a) Shinkai. S.: Ogawa. T.: Kusano. Y:: Manabe. O.: Kikukawa K.: (ioto, T.: Masudat T. J. tm. (hem. Soc. 1982, J1/, 1960) (b) Youhei. I.: Paul. K.: Yasushi. (): Yoshinori. I:: Hirosasu. Y.: Akira. 11. I. 1m. ('hem. Soc 2007. 129. 6396. (c) Roger. I. Coulston. H. O.: Stephen. F. L.: Christopher. J. E. I. Am. Chem. Soc. 2006. 128. 14750.

2. (a) Bisscll. R. A.: Cordova. E.: Kaifer. A. E.: Stoddart. I. F. Aature 
1994. 369. 133. (b) Badjic. J. D.: Balzani. V: Credi. A.: Silvi. S.: Stoddart. J. F. Science 2004. 303. 1845.

3. (a) Broumer. A. M.: Frochot. C.: Gatti. F. G.: Leigh. D. A.: Mottier L.: Paolucei. F: Roffia, S.: Wurpel, G. W. H. Science 2001, 291, 2124. (b) Shinkai. S.: Nakaji, T: Nishida, Y: Ogawa. T: Manabe. O. J. Am. Chem. Soc. 1980. 102. 5860. (c) Tomatsu. I.: Hashidzume. A.: Harada. A. J. An. Chem. Soc. 2006. 128. 2226.

4. (a) Armaroli. N.: Balzani. V: Collin. J.-P.: Gavina. P.: Sauvage. J.-P.: Ventura, B. J. Am. Chem. Soc. 1999. 121. 4397. (b) Lill. Y.: Flood A. H.: Stoddart J. F. J. Am. (Them. Soc. 2004. 126. 9150 .

5. (a) Gouloumis. A.: Lawson. R. C.: Vazquez. P.: Echegoven. L.: Torres. T. Tetrahedron 2002. 58.961. (b) Awasthy. A.: Bhatnagar. M.: Tomar. J.: Sharma. U. Bioinorg. Chent. Appt. 2006. 16

6. (a) Bako. P.: Mako, A.: Keglevich. G.; Menvart D. K: Sefesik;
T: Fekete. T. J. Incl. Phenom. 2006. 55. 295. (b) Torun. L: Robisont. T. W.: Krzykawski. J.: Purkiss. D. W.: Bartsch. R. A. Tetrahedron 2005. 61.8345.

7. (a) Gustowski, D. A.: Delgado. M.: Gatto. V. J.: Echegoyen, L: Gokel. G. W. J. Am. Chem. Soc. 1986, 108, 7553. (b) Barzegar. M:; Mousavi. M. F; Khajehsharifi, H:; Shamsipur, M.; Sharghi. H. IEEE Sensors J. 2005.5.392

8. (a) Stone. E. W.: Maki. A. H. J. Chem. Phys. 1962. 36. 1944. (b) Stauff. T. Photochem. Phorobiol. 1965. t. 1199.

9. (a) Licheng. S.; Jörg-von, G.: Jens, S.: Harry. K. Tetrahedron 1995. 51. 3535. (b) Rahman, M. A.; Kwon. N: Won. M: Hyun. M.; Shim, Y. Anal. Chem. 2004, 76. 3660

10. Delgado. M.: Gustowski. D. A.: Yoo. H. K.: Gatto. V. T.: Gokel. G. W.: Echegoyen. L. J. Ant Chent Soc. 1988. 110. 119.

11. Taziaux. D.: Soumillion. T.-Ph.: Habib-Tiwan. T.-L. J. Photochen. Photobiol. A: Chem. 2004, 162. 599. 